\title{
Helmet legislation and admissions to hospital for cycling related head injuries in Canadian provinces and territories: interrupted time series analysis
}

\author{
(C) $(1)(9)$ OPEN ACCESS
}

\author{
Jessica Dennis PhD candidate ${ }^{1}$, Tim Ramsay assistant professor ${ }^{2}$, Alexis $\mathrm{F}$ Turgeon assistant \\ professor $^{3}$, Ryan Zarychanski assistant professor ${ }^{4}$
}

1Division of Epidemiology, Dalla Lana School of Public Health, University of Toronto, 155 College Street, Toronto, ON, M5T 3M7, Canada; ${ }^{2}$ Ottawa Hospital Research Institute, Ottawa, ON, Canada; ${ }^{3}$ Division of Critical Care Medicine, Department of Anesthesiology, Population Health-Practice-changing Research Unit (Trauma-Emergency-Critical Care Medicine), Université Laval, QC, Canada; ${ }^{4}$ Departments of Internal Medicine and of Community Health Sciences, University of Manitoba, Winnipeg, MB, Canada

\begin{abstract}
Objective To investigate the association between helmet legislation and admissions to hospital for cycling related head injuries among young people and adults in Canada.

Design Interrupted time series analysis using data from the National Trauma Registry Minimum Data Set.

Setting Canadian provinces and territories; between 1994 and 2003, six of 10 provinces implemented helmet legislation.

Participants All admissions ( $\mathrm{n}=66 \mathrm{716}$ ) to acute care hospitals in Canada owing to cycling related injury between 1994 and 2008.

Main outcome measure Rate of admissions to hospital for cycling related head injuries before and after the implementation of provincial helmet legislation.

Results Between 1994 and 2008, 66716 hospital admissions were for cycling related injuries in Canada. Between 1994 and 2003, the rate of head injuries among young people decreased by $54.0 \%$ (95\% confidence interval $48.2 \%$ to $59.8 \%$ ) in provinces with helmet legislation compared with $33.1 \%(23.3 \%$ to $42.9 \%)$ in provinces and territories without legislation. Among adults, the rate of head injuries decreased by $26.0 \%$ ( $16.0 \%$ to $36.3 \%$ ) in provinces with legislation but remained constant in provinces and territories without legislation. After taking baseline trends into consideration, however, we were unable to detect an independent effect of legislation on the rate of hospital admissions for cycling related head injuries.
\end{abstract}

Conclusions Reductions in the rates of admissions to hospital for cycling related head injuries were greater in provinces with helmet legislation, but injury rates were already decreasing before the implementation of legislation and the rate of decline was not appreciably altered on introduction of legislation. While helmets reduce the risk of head injuries and we encourage their use, in the Canadian context of existing safety campaigns, improvements to the cycling infrastructure, and the passive uptake of helmets, the incremental contribution of provincial helmet legislation to reduce hospital admissions for head injuries seems to have been minimal.

\section{Introduction}

Bicyclists are vulnerable road users. Compared with car occupants, bicyclists are more than twice as likely to be fatally injured per person trip and up to 10 times more likely to be injured per kilometre travelled. ${ }^{12}$ Moreover, as with many transportation related injuries, cycling injuries are often to the head; such injuries account for approximately $30 \%$ of admissions to hospital for cycling related injuries ${ }^{3-6}$ and over $75 \%$ of cycling fatalities. ${ }^{78}$ A proportion of these injuries can be prevented by the use of helmets, ${ }^{9-12}$ and legislation mandating helmet use for all cyclists, or for cyclists under a given age (for example, 18 years), has been implemented in six of 10 Canadian provinces and countries such as Australia, New Zealand, and parts of the United States. Such laws, however, are contentious and the focus of active public debate. ${ }^{1314}$

Fuelling the debate is the uncertain effectiveness of legislation to reduce head injuries. Several studies have attempted to answer this fundamental question but have been limited by sample size 
or methodological quality. ${ }^{15-20}$ Controlled before and after studies do suggest a protective effect of legislation targeting young bicyclists, ${ }^{21-24}$ but only one of these studies, which examined cycling related deaths, accounted for baseline trends in cycling injury rates. ${ }^{22}$ Moreover, no controlled before and after study has investigated the association between helmet legislation and head injuries in adult cyclists. We therefore examined changes in the rate of cycling related head injuries associated with helmet legislation in young people and adults while accounting for baseline trends in the rate of cycling injuries.

\section{Methods}

We used a controlled, interrupted time series design-a series of observations taken at regular, evenly spaced intervals, before and after the implementation of an intervention, in both intervention and control groups. This design accounts for baseline trends and is among the strongest of quasi-experimental approaches for evaluating the effect of an intervention. ${ }^{25}$

\section{Data sources and variable definitions}

We analysed annual counts of admissions to hospital for cycling related injuries obtained from the National Trauma Registry Minimum Data Set, managed by the Canadian Institute for Health Information. The registry contains personal and diagnostic information on all admissions to acute care hospitals in Canada due to injury from 1994 onwards. The cause and nature of each patient's injuries are coded according to the international classification of diseases (ICD-9, ICD-9-CM, and ICD-10-CA), and up to 25 injuries are coded per patient. We included admissions to hospital due to a cycling injury that occurred in the 15 years between 1 April 1994 and 31 March 2008 (see supplementary table 1 for cycling injury codes) and we summed counts by fiscal year-for example, fiscal year 1994 runs from 1 April 1994 to 31 March 1995. The national trauma registry does not include information on helmet use.

We defined head injured cyclists as those with an injury to the brain, skull, scalp, or face (see supplementary table 2 for head injury codes). We also included the total number of admissions to hospital for cycling related injuries (that is, admissions due to a cycling injury to any body region, including the head) in our analysis to control for trends in admissions to hospital for cycling related head injuries that were attributable to factors other than helmet legislation.

Canada includes 10 provinces and three territories. Between 1994 and 2003, helmet laws were introduced in six provinces, and these provinces comprised the intervention group (table $1 \Downarrow$ ). Although adults are not specifically targeted by legislation in two of these provinces, a strong modifying effect of legislation aimed at young people on helmet use in adults in these provinces has been previously observed ${ }^{26}$ and so we grouped these provinces with the other intervention provinces. The four provinces and three territories that did not implement helmet legislation comprised the control group. We considered the year in which provincial legislation was enacted to be the time point at which the intervention occurred; all years thereafter were considered post-intervention. In Ontario and New Brunswick, where legislation was enacted after the Canadian cycling season (after September), we considered the intervention to have occurred in the subsequent year. We defined young people as those aged less than 18 years.

\section{Statistical analyses}

We used two methods to assess the association between helmet legislation and cycling related head injuries. Firstly, we calculated the annual rates of admissions to hospital for cycling related head injuries per 100000 person years in all provinces and in the territories. Population counts for the denominator were obtained from CANSIM (Canadian Socioeconomic Information Management System) ${ }^{27}$ Sparse injury counts among young people in the territories and in smaller provinces necessitated the estimation of crude rates for young people, whereas among adults we estimated age adjusted rates using three age strata (18-24 years, 25-44 years, and $\geq 45$ years) and the 2006 Canadian population as the standard population. We then estimated the percentage change in rates in the legislation group between 1994 and 2003 (the time over which legislation was implemented in these provinces), and we compared this change with the percentage change in the rates in the control group over this same period. We followed these same steps in the analysis of total admissions to hospital for cycling related injuries.

Secondly, using an over-dispersed Poisson segmented regression analysis, we modeled the annual rates of admissions to hospital for cycling related head injuries per total admissions to hospital for cycling related injuries - that is, using a different denominator than in the first analysis. Segmented regression is a statistical method used specifically for assessing the response to an intervention while controlling for baseline trends in interrupted time series studies (for more information see supplementary appendix 1). ${ }^{25} 28$ We included all available data from 1994 to 2008, specified separate models for young people and adults in each intervention province (12 models in total), and included interaction terms in each model to model the rate in the control group (see supplementary appendix 1 for model formulation).

Results of the segmented regression analysis were expressed in two ways. Firstly, we expressed the effect of legislation one year after its implementation within each intervention province as a rate ratio and its $95 \%$ confidence interval, with rate ratios $<1$ suggesting that the rate of head injuries one year after implementation of the legislation was less than if legislation had not been implemented - that is, that legislation was effective. Although we assessed the effect of legislation at only one time point (one year after its implementation), all time points contributed to model parameterisation and estimation of rate ratios. Thus, we averaged out seasonal or other variation in the injury rate in the year after the introduction of the legislation. The second way in which results of the segmented regression analysis were expressed was through the statistical significance of the interaction terms that compared the post-legislation changes in the rate of head injuries in the intervention province with those in the control group. All tests of statistical significance reflect a two sided $\alpha$ of 0.05 . Since error terms of consecutive observations may be correlated in a time series, we visually inspected plots of model residuals against time to ensure that no pattern suggesting autocorrelation was evident. We estimated the summary estimates of the effect of helmet legislation among young people and adults by combining individual rate ratios in a random effects model. All analyses were conducted with SAS 9.2.

\section{Results}

Between 1994 and 2008 we identified 66716 admissions to hospital for cycling related injuries across the Canadian provinces and territories (table $2 \Downarrow$ ). Head injuries accounted for 
$29.6 \%$ of these, and over two thirds of head injured cyclists had a brain injury. Overall, 19\% of head injured cyclists had a face injury without a concomitant scalp, skull, or brain injury.

Cyclists aged less than 18 years comprised $44.7 \%(n=29844)$ of admissions to hospital for injuries and $52.6 \%(n=10369)$ of admissions for head injuries, despite comprising approximately $20 \%$ of the Canadian population. The majority of injuries occurred in males $(75.0 \%, n=50004)$. Approximately $1 \%$ of admissions for head injuries were fatal compared with $0.4 \%$ of all admissions for injuries.

The rate of hospital admissions for cycling related head injuries in Canada among young people decreased from 17.0 to 4.9 per 100000 person years between 1994 and 2008 (fig $1 \Downarrow$ ). In provinces that implemented helmet legislation, the rate decreased steeply between 1994 and 2003, the time over which legislation was implemented, from 15.9 to 7.3 per 100000 person years, corresponding to a $54.0 \%$ (95\% confidence interval $48.2 \%$ to $59.8 \%$ ) reduction. In provinces and territories that did not implement helmet legislation, the rate of admissions for cycling related head injuries also decreased between 1994 and 2003, but to a lesser degree. The reduction in provinces without legislation was $33.2 \%$ ( $23.3 \%$ to $43.0 \%$ ), corresponding to a decrease from 19.1 to 12.9 per 100000 person years. Among adults, the rate of admissions for cycling related head injuries was low in all provinces and across all study years. Between 1994 and 2003, the rate of head injuries in adults in provinces with helmet legislation decreased by $26.2 \%$ ( $16.0 \%$ to $36.3 \%$ ), a reduction from 3.0 to 2.2 per 100000 person years, compared with a negligible increase in rates in provinces and territories with no legislation, from 2.7 to 2.8 per 100000 person years.

The rate of total hospital admissions for cycling related injuries also decreased across Canada among young people but not among adults between 1994 and 2008 (see supplementary figure 1). Between 1994 and 2003, the rate among young people decreased to a similar extent in provinces both with legislation (28.0\%, $95 \%$ confidence interval $22.8 \%$ to $33.2 \%$ ) and without legislation $(22.3 \%, 15.0 \%$ to $29.6 \%)$, suggesting fewer young cyclists, improvements to cycling safety, or a change in hospital admission policies. Among adults the rate of total hospital admissions for cycling related injuries increased between 1994 and 2003, but this increase, from 10.0 to 10.5 per 100000 person years in provinces that implemented helmet legislation, and from 9.7 to 10.0 per 100000 person years in provinces and territories with no such legislation, was not statistically significant in either group.

Using segmented regression analysis, we did not detect a statistically significant effect of helmet legislation on the rate of hospital admissions for cycling related head injuries per total admissions for cycling related injuries among young people in the year after legislation was implemented (fig $2 \Downarrow$ ). The age group of cyclists targeted by legislation $(<18$ years versus all ages) was not associated with meaningful changes in rate ratios for head injuries (fig 2). The rate ratio was statistically significant (indicating a protective effect of legislation) in only one province, New Brunswick, where legislation applies to all cyclists (fig 2). None of the interaction terms were statistically significant, indicating no difference in the post-legislation rate of head injuries in provinces with legislation compared with those without legislation. Among adults, a statistically significant protective effect of helmet legislation was detected in one province, British Columbia, where legislation applies to all cyclists (fig $3 \Downarrow$ ). None of the interaction terms were significant. Results did not change appreciably when face injuries were excluded from the definition of head injuries (see supplementary figures 2 and 3 ).

\section{Discussion}

Since 1994 in Canada the rate of bicycling injuries, including those to the head, has decreased among young people. In six provinces where helmet legislation was implemented, we observed a steep decline in the rate of hospital admissions for young people with cycling related head injuries (54\% reduction) compared with provinces and territories without legislation (33\% reduction). In adults over this same period we observed a $26 \%$ reduction in the rate of admissions for head injuries in provinces that implemented helmet legislation, compared with no reduction in provinces without legislation. While these results superficially suggest an important effect of legislation, after taking baseline trends into consideration we were unable to show an independent effect of helmet legislation on the rate of head injuries per hospital admission for a cycling related injury one year after the implementation of legislation, either overall or according to the age group of cyclists targeted by the legislation.

Three previous studies have investigated the effects of helmet legislation on bicycle related head injuries using a before and after design and a concurrent comparison group. ${ }^{2123}{ }^{29}$ All focused on paediatric populations. In a Canadian study that analysed data from the National Trauma Registry Minimum Data Set (years 1994 to 1997), the same data source used in our study, the authors concluded that helmet legislation was associated with a significant reduction in the rate of cycling related head injuries among Canadians aged 5-19 years. ${ }^{21}$ Using the same data source but with an extended period of follow-up, over which time two additional provinces implemented legislation, we replicated the results of this previous study in our initial analysis that did not adjust for baseline trends. In our time series analysis, we none the less could not confirm that the reduction in the rate of head injuries was an independent effect of helmet legislation above and beyond the concomitant declining trend in the rate of head injuries observed throughout Canada.

Helmets reduce the risk of injuries to the brain by up to $88 \%$, the head by up to $85 \%$, and the face by up to $65 \% .^{10-12}$ Laws that mandate the use of helmets increase the chance that cyclists will wear a helmet, especially when they apply to all cyclists. ${ }^{26} 30$ Given this evidence, why is it difficult to detect a decrease in hospital admissions for cycling related head injuries after the implementation of helmet legislation? Concurrent interventions that improve cycling safety combined with municipality specific helmet legislation are two possible explanations. The Canadian Cycling Association's CAN-BIKE programme to promote cycling safety, for example, has been taught in Canada since $1985,{ }^{31}$ and local educational programmes, media campaigns, and subsidised or free helmet distribution programmes are also known to have occurred in Canada around the time legislation was implemented (table 1). ${ }^{32-37}$ Similarly, changes to cycling infrastructure over the study period (for example, traffic calming, and designated bicycle lanes and routes) ${ }^{38-41}$ could have confounded associations with helmet legislation. In provinces and territories without legislation, several municipalities implemented helmet legislation between 1994 and 2003. ${ }^{42} 43$ Notably, seven municipalities in Newfoundland and Labrador, including St John's, the province's largest municipality, implemented bylaws that may have contributed to the steep decrease in cycling rated head injury rates we observed in this province. $^{44}$

A third possible explanation for our results is that the effectiveness of helmets is greater for mild and moderate head injuries than for the severe head injuries captured by hospital 
admission data. Diagnostic and prognostic improvements over time that allowed for the treatment of patients with mild and moderate head injuries in emergency rooms, as opposed to in inpatient hospital wards, could have further impeded our ability to detect an effect of helmet legislation, if one exists. ${ }^{45} 46$

While minimal enforcement may compromise the effectiveness of helmet legislation, fear of the police and of fines motivates helmet use,$^{47}$ and despite nominal fines and few issued tickets, helmet use rose dramatically in provinces immediately after the enactment of legislation (table 1). ${ }^{30}$

\section{Strengths and limitations of this study}

The National Trauma Registry Minimum Data Set captures information on all hospital admissions for cycling related injuries in Canada. Cyclists who die from their injuries before reaching a hospital are not included. Additional data on emergency room visits would have been beneficial, both to make inferences on the association between helmet legislation and milder head injuries and to refine counts of head injuries in small provinces and in the territories. None the less, before 2002 no province or territory systematically reported data on visits to emergency rooms to a national database. The National Trauma Registry Minimum Data Set also makes no distinction between cyclists injured on-road and off-road (for example, while jumping on BMX bikes or mountain biking), yet provincial helmet laws apply only to on-road cyclists. Helmets are standard in off-road cycling, with usage more than $80 \%$ in the 1990 s and nearly $100 \%$ in recent studies. ${ }^{48-50}$ This increase, coupled with improvements to helmet design, may have contributed to a reduction in bicycle related head injuries in provinces where off-road cycling is common (British Columbia, Alberta, Quebec).

Data on exposure to cycling are desirable, yet were unavailable for Canada at the time helmet legislation was implemented. Recent data from the Canadian Community Health Survey indicate that bicycle use varies across provinces, ${ }^{26}$ reflecting differences in climate and cycling infrastructure. Variation in cycling possibly contributes to differences in cycling injury rates between provinces. Within a province, however, the introduction of helmet legislation does not discourage bicycle use and thus permits assessment of helmet legislation on cycling related head injuries. ${ }^{26} 51$

One further limitation of our study is the small number of time points, especially preintervention, which may have reduced the power of the segmented regression analysis. ${ }^{25} 2852$ In small provinces, few observations at each time point resulted in wide confidence intervals.

Strengths of our study include the number of provinces, territories, and years analysed, combined with our use of descriptive statistics and statistical methods for interrupted time series data that explicitly considered baseline trends. This is the first study to use a controlled before and after design to assess the association between helmet legislation and cycling related head injuries in adults, as well as the first controlled study to incorporate background trends in rates of injury. Results from our study are timely and relevant, following ongoing debates in the lay and medical press as to the merit of bicycle helmet laws. ${ }^{53-56}$

\section{Conclusion}

From 1994 to 2008, we observed a substantial and consistent decrease in the rate of hospital admissions for cycling related head injuries across Canada. Reductions were greatest in provinces with helmet legislation. Rates of admissions for head injuries, however, were decreasing before the implementation of provincial helmet legislation and did not seem to change in response to legislation. While helmets reduce head injuries and their use should be encouraged, this study suggests that, in the Canadian context of provincial and municipal safety campaigns, improvements to the cycling infrastructure, and the passive uptake of helmets, the incremental contribution of provincial helmet legislation to reduce the number of hospital admissions for head injuries is uncertain to some extent, but seems to have been minimal.

We thank the peer reviewers and Sarah Namer for their thoughtful comments that improved the quality of our manuscript.

Contributors: JD, TR, and RZ conceived and designed the study. JD analysed the data and all authors contributed to its interpretation. JD drafted the manuscript and all authors participated in the revision process and have approved this submission for publication. JD and RZ had full access to all of the data in the study and can take responsibility for the integrity of the data and the accuracy of the data analysis.

Funding: JD is a Canadian Institute of Health Research Vanier graduate scholar, AFT is a recipient of a research career award from the Fonds de la Recherche du Québec-Santé, and $R Z$ is a recipient of a RCT-mentorship award from the Canadian Institute of Health Research. None of the funders influenced the conduct of this research.

Competing interests: All authors have completed the ICMJE uniform disclosure form at www.icmje.org/coi_disclosure.pdf (available on request from the corresponding author) and declare: no support from any organisation for the submitted work; no financial relationships with any organisations that might have an interest in the submitted work in the previous three years; no other relationships or activities that could appear to have influenced the submitted work.

Ethical approval: Not required.

Data sharing: Cycling injury counts by province and year are available from the corresponding author at jessica.dennis@mail.utoronto.ca.

1 Beck LF, Dellinger AM, O'Neil ME. Motor vehicle crash injury rates by mode of travel, United States: using exposure-based methods to quantify differences. Am J Epidemiol 2007;166:212-8.

2 Pucher J, Dijkstra L. Promoting safe walking and cycling to improve public health: lessons from the Netherlands and Germany. Am J Public Health 2003:93:1509-16.

3 Mehan TJ, Gardner R, Smith GA, McKenzie LB. Bicycle-related injuries among children and adolescents in the United States. Clin Pediatr (Phila) 2009;48:166-73.

4 Shah S, Sinclair SA, Smith GA, Xiang H. Pediatric hospitalizations for bicycle-related injuries. Inj Prev 2007;13:316-21.

5 Rosenkranz KM, Sheridan RL. Trauma to adult bicyclists: a growing problem in the urban environment. Injury 2003;34:825-9.

6 Linn S, Smith D, Sheps S. Epidemiology of bicycle injury, head injury, and helmet use among children in British Columbia: a five year descriptive study. Canadian Hospitals Injury, Reporting and Prevention Program (CHIRPP). Inj Prev 1998;4:122-5.

7 Rowe BH, Rowe AM, Bota GW. Bicyclist and environmental factors associated with fatal bicycle-related trauma in Ontario. CMAJ 1995;152:45-53.

8 Spence LJ, Dykes EH, Bohn DJ, Wesson DE. Fatal bicycle accidents in children: a plea for prevention. J Pediatr Surg 1993;28:214-6.

9 Thompson DC, Nunn ME, Thompson RS, Rivara FP. Effectiveness of bicycle safety helmets in preventing serious facial injury. JAMA 1996;276:1974-5.

10 Thompson DC, Rivara FP, Thompson R. Helmets for preventing head and facial injuries in bicyclists. Cochrane Database Syst Rev 2000;(2):CD001855.

11 Elvik R. Publication bias and time-trend bias in meta-analysis of bicycle helmet efficacy: a re-analysis of Attewell, Glase and McFadden, 2001. Accid Anal Prev 2011:43:1245-51.

12 Amoros E, Chiron M, Martin JL, Thelot B, Laumon B. Bicycle helmet wearing and the risk of head, face, and neck injury: a French case-control study based on a road trauma registry. Inj Prev 2012;18:27-32.

13 Hannay C. Your take: should cyclists wear helmets? [Internet]. The Globe and Mail; 2012. www.theglobeandmail.com/community/digital-lab/your-take-should-cyclists-wear-helmets/ article4348007/.

14 Guerchani S. Le casque de vélo obligatoire pour les mineurs? [Internet]. Le Journal de Montréal; 2012. www.journaldemontreal.com/2012/06/20/le-casque-de-velo-obligatoirepour-les-mineurs.

15 Cameron MH, Vulcan AP, Finch CF, Newstead SV. Mandatory bicycle helmet use following a decade of helmet promotion in Victoria, Australia—an evaluation. Accid Anal Prev 1994;26:325-37.

16 Borglund ST, Hayes JS, Eckes JM. Florida's bicycle helmet law and a bicycle safety educational program: did they help? J Emerg Nurs 1999;25:496-500.

17 Scuffham P, Alsop J, Cryer C, Langley JD. Head injuries to bicyclists and the New Zealand bicycle helmet law. Accid Anal Prev 2000;32:565-73.

18 Liller KD. Children's bicycle helmet use and injuries in Hillsborough County, Florida before and after helmet legislation. Inj Prev 2003;9:177-9. 


\section{What is already known on this topic}

Cyclists are vulnerable road users; head injuries among cyclists account for $75 \%$ of cycling related fatalities

Debate exists about whether or not helmet legislation is an effective strategy to reduce serious head injuries among child and adult

cyclists

\section{What this study adds}

When baseline trends in cycling related injury rates were considered, the overall rates of head injuries were not appreciably altered by helmet legislation

In the context of provincial and municipal safety campaigns, improvements to the cycling infrastructure, and the passive uptake of helmets, the incremental benefit of provincial helmet legislation to reduce admissions to hospital for head injuries is substantially uncertain

19 Castle SL, Burke RV, Arbogast H, Upperman JS. Bicycle helmet legislation and injury patterns in trauma patients under age 18. J Surg Res 2012;173:327-31.

20 Walter SR, Olivier J, Churches T, Grzebieta R. The impact of compulsory cycle helmet legislation on cyclist head injuries in New South Wales, Australia. Accid Anal Prev 2011:43:2064-71.

21 Macpherson AK, To TM, Macarthur C, Chipman ML, Wright JG, Parkin PC. Impact of mandatory helmet legislation on bicycle-related head injuries in children: a population-based study. Pediatrics 2002;110:e60.

22 Wesson DE, Stephens D, Lam K, Parsons D, Spence L, Parkin PC. Trends in pediatric and adult bicycling deaths before and after passage of a bicycle helmet law. Pediatrics 2008:122:605-10

23 Lee BH-Y, Schofer JL, Koppelman FS. Bicycle safety helmet legislation and bicycle-related non-fatal injuries in California. Accid Anal Prev 2005;37:93-102.

24 Macpherson A, Spinks A. Bicycle helmet legislation for the uptake of helmet use and prevention of head injuries. Cochrane Database Syst Rev 2008;(2):CD005401.

25 Wagner AK, Soumerai SB, Zhang F, Ross-Degnan D. Segmented regression analysis of interrupted time series studies in medication use research. $J$ Clin Pharm Ther 2002;27:299-309

26 Dennis J, Potter B, Ramsay T, Zarychanski R. The effects of provincial bicycle helmet legislation on helmet use and bicycle ridership in Canada. Inj Prev 2010;16:219-24.

27 Statistics Canada. Table 510001: estimates of population by age group and sex for July 1, Canada, provinces and territories, annually (persons). 2010. http://dc1.chass.utoronto. ca/cgi-bin/cansimdim/c2 searchCansim.pl.

28 Shardell M, Harris AD, El-Kamary SS, Furuno JP, Miller RR, Perencevich EN. Statistical analysis and application of quasi experiments to antimicrobial resistance intervention studies. Clin Infect Dis 2007;45:901-7.

$29 \mathrm{Ji} \mathrm{M}$, Gilchick RA, Bender SJ. Trends in helmet use and head injuries in San Diego County: the effect of bicycle helmet legislation. Accid Anal Prev 2006;38:128-34.

30 Karkhaneh M. Effectiveness of bicycle helmet legislation to increase helmet use: a systematic review. Inj Prev 2006;12:76-82.

31 Canadian Cycling Association. CAN-BIKE program [Internet]. 2012. www.canbike.net/ cca_pages/index.htm.

32 Leblanc JC, Beattie TL, Culligan C. Effect of legislation on the use of bicycle helmets. CMAJ 2002;166:592-5.

33 Parkin PC, Spence LJ, Hu X, Kranz KE, Shortt LG, Wesson DE. Evaluation of a promotional strategy to increase bicycle helmet use by children. Pediatrics 1993:91:772-7.

34 Parkin PC, Khambalia A, Kmet L, Macarthur C. Influence of socioeconomic status on the effectiveness of bicycle helmet legislation for children: a prospective observational study. Pediatrics 2003;112:e192-6.

35 Farley C, Haddad S, Brown B. The effects of a 4-year program promoting bicycle helmet use among children in Quebec. Am J Public Health 1996;86:46-51.

36 Foss R, Beirness DJ. Bicycle helmet use in British Columbia: effects of the helmet use law: Traffic Injury Research Foundation. University of North Carolina Highway Safety Research Center, 2000

37 Hagel BE. Bicycle helmet prevalence two years after the introduction of mandatory use legislation for under 18 year olds in Alberta, Canada. Inj Prev 2006;12:262-5.

38 Reynolds CC, Harris M, Teschke K, Cripton PA, Winters M. The impact of transportation infrastructure on bicycling injuries and crashes: a review of the literature. Environ Health 2009:8:47.
39 Lusk AC, Furth PG, Morency P, Miranda-Moreno LF, Willett WC, Dennerlein JT. Risk of injury for bicycling on cycle tracks versus in the street. Inj Prev 2011;17:131-5.

$40 \mathrm{Kim}$ J-K, Kim S, Ulfarsson GF, Porrello LA. Bicyclist injury severities in bicycle-motor vehicle accidents. Accid Anal Prev 2007;39:238-51.

41 Bunn F, Collier T, Frost C, Ker K, Roberts I, Wentz R. Area-wide traffic calming for preventing traffic related injuries. Cochrane Database Syst Rev 2003;(1):CD003110.

42 Safe Kids Canada. Bicycle helmet legislation chart. 2011. www.safekidscanada.ca/ Professionals/Advocacy/Documents/26783-BikeHelmetLegislationChart.pdf.

43 City of Côte Saint-Luc, Province of Quebec. By-law to render the wearing of bicycle helmets obligatory in the city of Côte Saint-Luc. 1992. www.cotesaintluc.org/files/u1/city_ clerk/bylaws/Bicycle helmets/bl 2103.pdf.

44 Association of Registered Nurses of Newfoundland and Labrador. Mandatory bicycle helmet use in Newfoundland and Labrador. 2005. www.arnnl.ca/documents/publications/ Mandatory_Bicycle_Helmet_Use_in_NL_April_06.pdf.

45 Tator $\mathrm{CH}$. Brain injury is a major problem in Canada and annual incidence is not declining Can J Neurol Sci 2010;37:714-5.

46 Colantonio A, Saverino C, Zagorski B, Swaine B, Lewko J, Jaglal S, et al. Hospitalizations and emergency department visits for TBI in Ontario. Can J Neurol Sci 2010;37:783-90.

47 Finch CF. Teenagers' attitudes towards bicycle helmets three years after the introduction of mandatory wearing. Inj Prev 1996;2:126-30

48 Rivara FP, Thompson DC, Thompson RS, Rebolledo V. Injuries involving off-road cycling J Fam Pract 1997;44:481-5.

49 Chow TK, Bracker MD, Patrick K. Acute injuries from mountain biking. West. J Med 1993;159:145-8.

50 Romanow NTR, Hagel BE, Nguyen M, Embree T, Rowe BH. Mountain bike terrain park-related injuries: an emerging cause of morbidity. Int J Inj Contr Saf Promot 2012;1-18.

51 Macpherson AK, Parkin PC, To TM. Mandatory helmet legislation and children's exposure to cycling. Inj Prev 2001;7:228-30.

52 Zhang F, Wagner AK, Ross-Degnan D. Simulation-based power calculation for designing interrupted time series analyses of health policy interventions. J Clin Epidemiol 2011;64:1252-61.

53 Wardlaw M. Butting heads over bicycle helmets. CMAJ 2002;167:337-8-authorreply338-9.

54 DeMarco TJ. Butting heads over bicycle helmets. CMAJ 2002;167:337-authorreply338-9.

55 Hagel B. Arguments against helmet legislation are flawed. BMJ 2006;332:725-6.

56 Robinson DL. No clear evidence from countries that have enforced the wearing of helmets. BMJ 2006;332:722-5.

\section{Accepted: 15 April 2013}

\section{Cite this as: BMJ 2013;346:f2674}

This is an Open Access article distributed in accordance with the Creative Commons Attribution Non Commercial (CC BY-NC 3.0) license, which permits others to distribute, remix, adapt, build upon this work non-commercially, and license their derivative works on different terms, provided the original work is properly cited and the use is non-commercial. See: http://creativecommons.org/licenses/by-nc/3.0/. 


\section{Tables}

\begin{tabular}{|c|c|c|c|c|c|c|c|}
\hline \multicolumn{8}{|c|}{ Table 1| Bicycle helmet legislation in Canadian provinces and territories } \\
\hline \multirow[b]{2}{*}{ Province or territory } & \multirow{2}{*}{$\begin{array}{c}\text { Date } \\
\text { implemented }\end{array}$} & \multirow[b]{2}{*}{ Penalty (\$C) } & \multirow[b]{2}{*}{ Enforcement } & \multirow[b]{2}{*}{ Cointerventions } & \multicolumn{3}{|c|}{ Helmet use } \\
\hline & & & & & Prelegislation & Post-legislation & $2009(\%)^{*}$ \\
\hline \multicolumn{8}{|l|}{$\begin{array}{l}\text { Legislation applies to } \\
\text { all cyclists: }\end{array}$} \\
\hline New Brunswick & $\begin{array}{c}\text { December } \\
1995\end{array}$ & 21 & $\begin{array}{l}\text { No information } \\
\text { available }\end{array}$ & No information available & $\begin{array}{l}\text { No information } \\
\text { available }\end{array}$ & $\begin{array}{l}\text { No information } \\
\text { available }\end{array}$ & 51 \\
\hline British Columbia & $\begin{array}{c}\text { September } \\
1996\end{array}$ & 100 & $\begin{array}{l}\text { No information } \\
\text { available }\end{array}$ & $\begin{array}{l}\text { Province wide safe cycling } \\
\text { promotion programme } \\
\text { (education, media, helmet } \\
\text { rebate) launched in } 1995^{36}\end{array}$ & $47 \%$ in $1995^{36}$ & $72 \%$ in $1999^{36}$ & 59 \\
\hline Nova Scotia & July 1997 & $\begin{array}{l}25 \text { for first } \\
\text { offence, } 50 \text { for } \\
\text { second, } 100 \text { for } \\
\text { third or } \\
\text { subsequent } \\
\text { offences }\end{array}$ & $\begin{array}{l}60 \text { tickets issued in } \\
1997,176 \text { in } 1998 \\
\text { and } 113 \text { in } 1999^{32}\end{array}$ & $\begin{array}{c}\text { Extensive media campaign } \\
\text { promoting law launched two } \\
\text { months before its } \\
\text { implementation }\end{array}$ & $36 \%$ in $1995^{32}$ & $84 \%$ in $1999^{32}$ & 66 \\
\hline Prince Edward Island & July 2003 & $\begin{array}{l}120 \text { or } \\
\text { participation in } 2 \\
\text { hour safety } \\
\text { seminar }\end{array}$ & $\begin{array}{c}3 \text { tickets and multiple } \\
\text { warnings issued } \\
\text { between } 2003 \text { and } \\
2009 \dagger\end{array}$ & No information available & $\begin{array}{c}\text { No information } \\
\text { available }\end{array}$ & $\begin{array}{l}\text { No information } \\
\text { available }\end{array}$ & 51 \\
\hline \multicolumn{8}{|l|}{$\begin{array}{l}\text { Legislation applies to } \\
\text { cyclists aged }<18 \\
\text { years: }\end{array}$} \\
\hline Ontario & October 1995 & 60 & $\begin{array}{c}\text { Minimal } \\
\text { enforcement }^{30}\end{array}$ & $\begin{array}{l}\text { Prelegislation helmet } \\
\text { discounts, media } \\
\text { campaigns, and targeted } \\
\text { school helmet promotion } \\
\text { activities }^{3033}\end{array}$ & $\begin{array}{l}\text { Young people: } \\
44 \% \text { in } 1994^{33}\end{array}$ & $\begin{array}{l}\text { Young people: } 66 \% \\
\text { in } 1997^{33}\end{array}$ & 34 \\
\hline Alberta & May 2002 & 69 & $\begin{array}{l}16 \text { tickets issued in } \\
2003,48 \text { in } 2004^{37}\end{array}$ & $\begin{array}{l}\text { Public health awareness } \\
\text { campaigns and targeted } \\
\text { school health activities } \\
\text { implemented in } 2004^{37}\end{array}$ & $\begin{array}{l}\text { Young people: } \\
28 \% \text { in } 2000 \\
\text { adults: } 49 \% \text { in } \\
2000^{37}\end{array}$ & $\begin{array}{l}\text { Young people: } 83 \% \\
\text { in } 2004, \text { adults: } \\
48 \% \text { in } 2004^{37}\end{array}$ & 48 \\
\hline \multicolumn{8}{|l|}{ No legislation: } \\
\hline Manitobał & - & - & - & - & - & - & 22 \\
\hline $\begin{array}{l}\text { Newfoundland and } \\
\text { Labrador }\end{array}$ & - & - & - & - & - & - & 38 \\
\hline Saskatchewan & - & - & - & - & - & - & 23 \\
\hline Quebec & - & - & - & - & - & - & 26 \\
\hline Northwest Territories & - & - & - & - & - & - & 28 \\
\hline Yukon & - & - & - & - & - & - & 51 \\
\hline Nunavut & - & - & - & - & - & - & - \\
\hline
\end{tabular}

*Information from: Bicycle helmet use, 2009. Statistics Canada; 2011. www.statcan.gc.ca/pub/82-625-x/2010002/article/11274-eng.htm. Estimates of helmet use in Nunavut were too unreliable to be published.

†Information from: Bike helmet law needs better enforcement, says MLA. CBC News; 2009. www.cbc.ca/news/canada/prince-edward-island/story/2009/05/05/peibike-helmet-law.html.

¥Legislation mandating helmet use for cyclists less than 18 years of age was tabled by the Manitoba government 23 May 2012. 
Table 2| Characteristics of cyclists admitted to hospital in Canada, 1 April 1994 to 31 March 2008

\begin{tabular}{|c|c|c|c|c|}
\hline \multirow[b]{2}{*}{ Characteristics } & \multicolumn{2}{|c|}{ Injured cyclists ( $n=66716$ ) } & \multicolumn{2}{|c|}{ Head injured cyclists ( $n=19732$ ) } \\
\hline & No & $\%(95 \% \mathrm{Cl})$ & No & $\%(95 \% \mathrm{Cl})$ \\
\hline \multicolumn{5}{|l|}{ Type of head injury*: } \\
\hline Brain & - & - & 13340 & 67.6 (67.0 to 68.3 ) \\
\hline Scalp or skull & - & - & 4770 & 24.2 (23.6 to 24.8$)$ \\
\hline Face & - & - & 7010 & 35.5 (34.9 to 36.2 ) \\
\hline \multicolumn{5}{|l|}{ Age (years): } \\
\hline$<18$ & 29844 & 44.7 (44.4 to 45.1$)$ & 10369 & 52.6 (51.9 to 53.3$)$ \\
\hline $18-24$ & 5765 & 8.6 (8.4 to 8.9$)$ & 1847 & 9.4 (9.0 to 9.8$)$ \\
\hline $25-44$ & 15217 & 22.8 (22.5 to 23.1$)$ & 3798 & $19.3(18.7$ to 19.8$)$ \\
\hline$\geq 45$ & 15890 & $23.8(23.5$ to 24.1$)$ & 3718 & 18.8 (18.3 to 19.4$)$ \\
\hline Males & 50004 & 75.0 (74.6 to 75.3$)$ & 15249 & 77.3 (76.7 to 77.9$)$ \\
\hline Discharge status dead & 267 & $0.4(0.3$ to 0.5$)$ & 224 & $1.1(1.0$ to 1.3$)$ \\
\hline
\end{tabular}

${ }^{*}$ Cyclists may have had more than one type of head injury. 


\section{Figures}



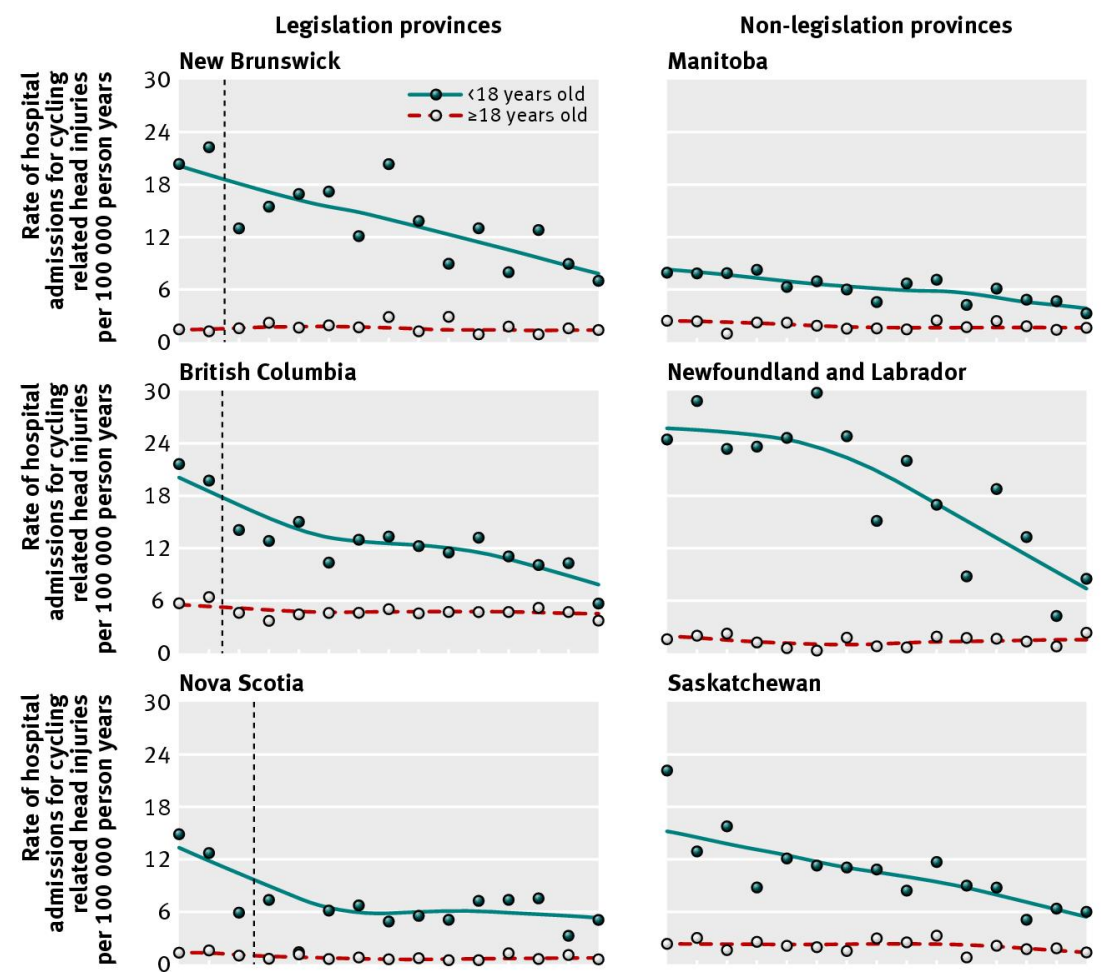

Saskatchewan
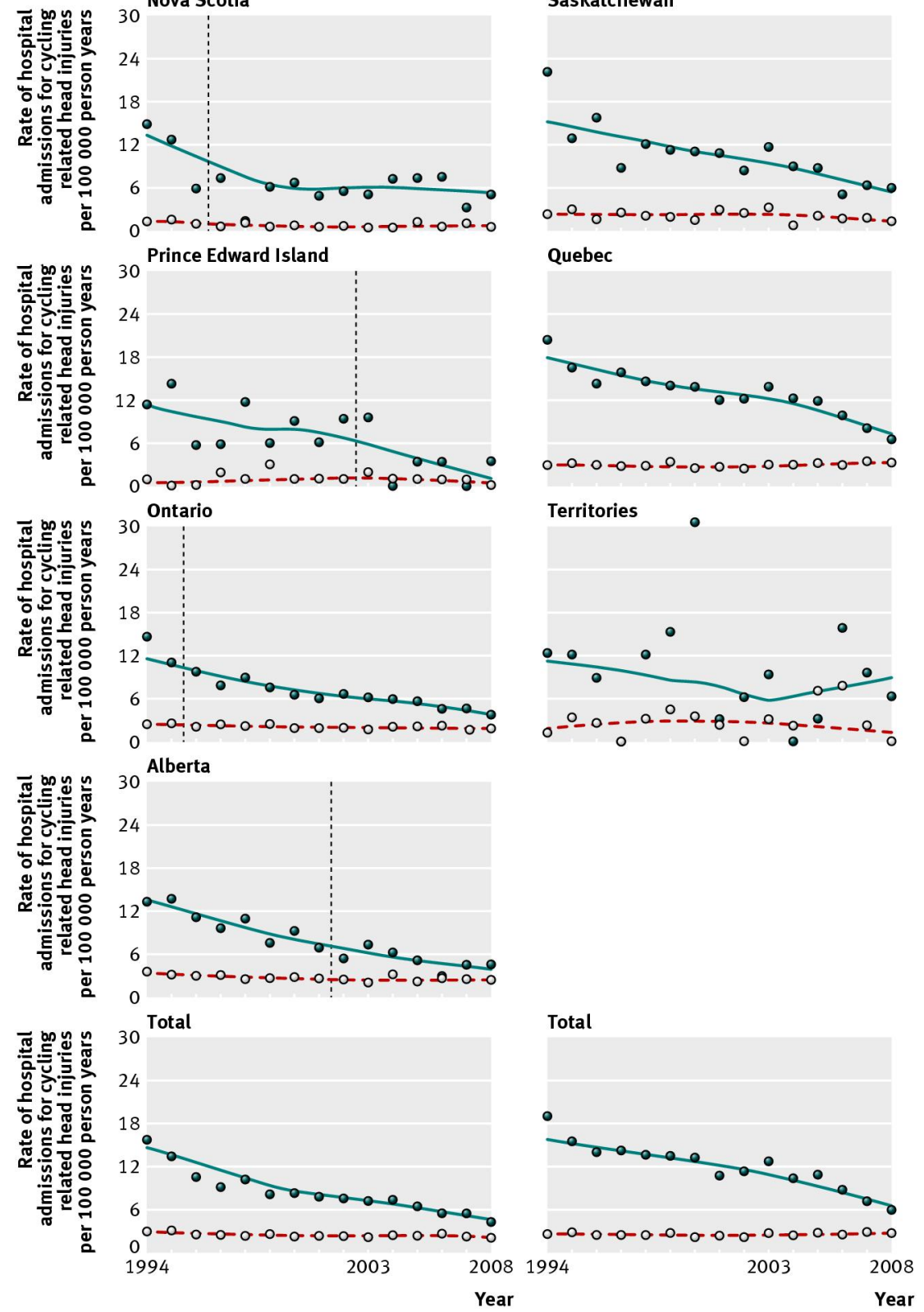

Fig 1 Annual rate of hospital admissions for cycling related head injuries, 1994 to 2008, in Canadian provinces and territories, and in Canadian provinces and territories grouped by bicycle helmet legislation status. Rates are connected by a LOESS regression line. Vertical bars indicate year legislation was enacted. Legislation in Ontario and Alberta targeted only cyclists aged less than 18 years 


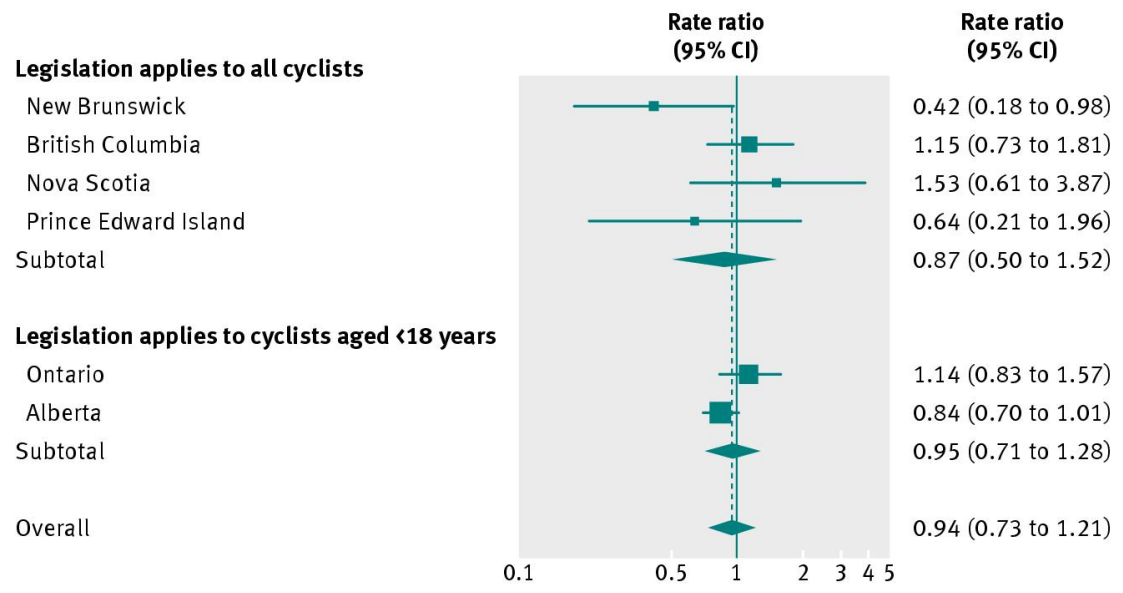

Fig 2 Change in rate of hospital admissions for head injuries per injured cyclist among cyclists aged less than 18 years one year after implementation of bicycle helmet legislation. Rate ratios $<1$ suggest a protective effect of helmet legislation. The area of the square is proportionate to the weight of each province in the summary estimate

Legislation applies to all cyclists

New Brunswick

British Columbia

Nova Scotia

Prince Edward Island

Subtotal

Legislation applies to cyclists aged $\ll 18$ years Ontario

Alberta

Subtotal

Overall

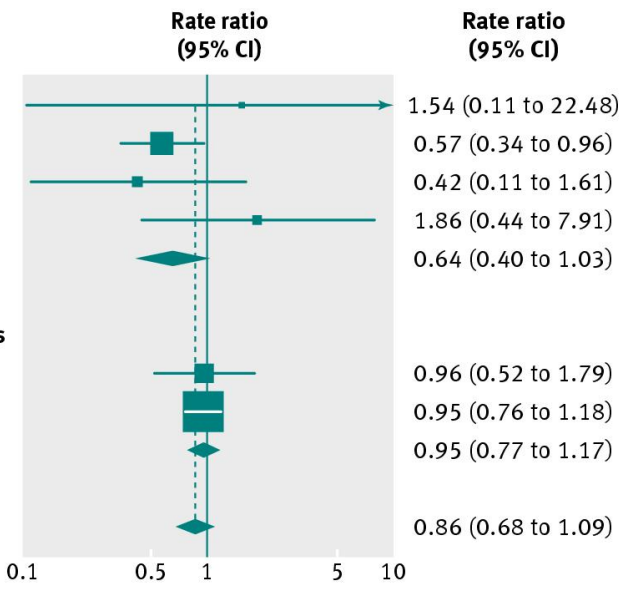

Fig 3 Change in rate of hospital admissions for head injuries per injured cyclist among cyclists aged 18 years and older one year after implementation of bicycle helmet legislation. Rate ratios $<1$ suggest a protective effect of helmet legislation. The area of the square is proportionate to the weight of each province in the summary estimate 